\title{
非冷却赤外線センサシステムにおける視認性改善処理
}

$\begin{array}{llcccc}\text { 非会員 } & \text { 林 } & \text { 健一* } & \text { 非会員 } & \text { 長嶋 } & \text { 満宏* } \\ \text { 非会員 } & \text { 蘇原 } & \text { 祥夫* } & \text { 正 員 } & \text { 和田 } & \text { 英男* } \\ \text { 非会員 } & \text { 梶谷 } & \text { 淳** } & & & \end{array}$

\section{Improved Recognition of Image Processing for an Uncooled Infrared Sensor System}

Ken-ichi Hayashi*, Non-member, Mitsuhiro Nagashima*, Non-member, Yoshio Sohara*, Non-member,

Hideo Wada*, Member, Atsushi Kajigaya**, Non-member

The low cost improved recognition of an uncooled infrared image processing has been required urgently for the development of high sensitive uncooled sensor like a cooled sensor. In this study, the uncooled infrared image taken by YBaCuO bolometer camera was improved with applying a special low cost image processing systems. The improved image with this processing exhibited not only the edge enhancement in a large contrast area but also the suppression of heat noise in a small contrast area. It is clarified that this improved recognition image processing is easy to realize at low cost, and the demand for this image processing will be expected to grow up as the use of uncooled infrared sensor system increases.

キーワード : 非冷却赤外線センサ, $\mathrm{YBaCuO}$ ボロメータ, 熱画像

Keywords : uncooled infrared sensor, $\mathrm{YBaCuO}$ bolometer, thermal imaging

\section{1. まえがき}

非冷却赤外線撮像装置は, 冷却装置が不要であるため, 小型, 軽量, 安価という点で優れているが, 個人携行用暗 視装置等の赤外線イメージング技術の応用に対して，冷却 型赤外線撮像装置に匹敵する高性能化が求められている。 非冷却赤外線センサの高性能化の方策としては, 検知素子 の高感度化と画像処理の改善が挙げられるが, 近年, $\mathrm{VOx}^{(1)(2) や} \mathrm{YBaCuO}(\mathrm{YBCO})^{(3)}$ 等の高感度ボロメータ検知素 子材料が報告されている一方, 画像処理の改善に関しても 簡易な装置による視認性の向上が期待されている。非冷却 赤外線センサの視認性においては, 熱によるランダムノイ ズが問題となっている。このノイズは，センサ部を極低温 まで泠却しないために発生しているノイズで, これを画像 処理によって抑制することが，冷却型赤外線センサレベル にまで視認性を向上させる重要な点になる。

赤外線映像はモノクロで表示されるため, 冷却型赤外線

* 防衛庁技術研究本部第 2 研究所

厂154-8511 東京都世田谷区池尻 1-2-24

2nd Research Center, Technical Research and Development Institute, Japan Defense Agency

1-2-24, Ikejiri, Setagaya-ku, Tokyo 154-8511

** 三菱電機㑣鎌倉製作所

$\overline{\mathrm{T}} 247-8520$ 神奈川県鎌倉市上町屋 325 番地

Kamakura Works, Mitsubishi Electric Corp.

325, Kamakura-shi, Kanagawa 247-8520
センサでは, ダイナミックレンジが広いセンサシステムの 方が視認性は高い。ダイナミックレンジは, 撮像装置や表 示装置に応じて減少し, 明るい部分や暗い部分の細部情報 が失われることが多いため, 画像のダイナミックレンジを 局所的に改善することにより視認性向上を図る試みがなさ れている(4)。このような通常の視認性改善処理では, 赤外線 センサで取得した映像に対して, エッジ強調による目標抽 出処理の実行後にヒストグラム平坦化処理 ${ }^{(5)(6)}$ が行われて いる。ここでいうヒストグラム平坦化（HE）処理とは, 頻 度の高い濃淡領域は拡大し, 頻度の低い濃淡領域は縮小寸 る様な階調変換を行って, 変換後の濃度ヒストグラムが全 ての濃度において一様になるようにする画像処理であ $ろ^{(4) \sim(6)}$ 。

一方, 非冷却赤外線センサでは, ダイナミックレンジが 狭いために, エッジ強調過程でコントラストの低い領域の ランダムノイズが強調されると, 視認性の向上が困難とな る。そこで本研究では, 特に目標抽出処理過程の改善のた め, 輝度が低い領域ではスムージングが働く新方式局所フ イルタを導入し, 非冷却赤外線映像の視認性向上を図った。

\section{2. システムの概要}

〈2·1〉YBCO ボロメータ 本研究で用いた非冷却赤 外線センサは, YBCO ボロメータ検知方式により画像取得 するものである。その非冷却赤外線センサにより撮像した 
表 1 非冷却赤外線センサの主要性能

Table 1. The main properties of the uncooled infrared sensor.

\begin{tabular}{ll} 
Detection method & YBCO microbolometer \\
Pixel number & $320[\mathrm{H}] \times 240[\mathrm{~V}]$ \\
Pixel size & $40 \mu \mathrm{m} \times 40 \mu \mathrm{m}$ \\
Fill factor & $90 \%$ \\
Thermal conductance & $1.3 \times 10^{-7} \mathrm{~W} / \mathrm{K}$ \\
Heat capacity & $2.2 \times 10^{-9} \mathrm{~J} / \mathrm{K}$ \\
TCR & $-3.2 \% / \mathrm{K}$ \\
IR absorption & $69 \%$ \\
Responsivity & $5.9 \times 10^{5} \mathrm{~V} / \mathrm{W}$ \\
NETD (f/1.0) & $0.08 \mathrm{~K}$ \\
\hline
\end{tabular}

映像に対して，簡易システムで構成された局所フィルタを 用いて画像処理を行い, 視認性の改善を図っている。その センサ部の主要性能は表 1 に示すとおりであり, 現用の VOx ボロメータ検知方式に比べて感度が 2 倍程度優れている。

〈2·2〉画像処理システム 画像処理部は, ビデオキ ヤプチャーボードを内蔵した汎用パーソナルコンピュータ から成っており，インストールされた汎用画像処理ソフト ウェア（IPLab Ver.3.06）と視認性改善処理ソフトウェア（三 菱電機(侏製）を起動させることで，容易に画像の取り込み と画像処理ができる。画像処理手順として，まず局所フィ ルタのサイズを設定した後に，全画面領域に対して画像の エッジ強調または平滑を行って画像の認識度を高め, HE 処 理によりダイナミックレンジの有効利用を図った。

\section{3. 実験及び結果}

画像取得に関して，まず通常行われている局所フィルタ 処理の問題点を取り上げる。次に視認性に関するフィルタ サイズの依存性を調べた。フィルタサイズは, 画素サイズ によって表すこととし，水平方向画素数 $\times$ 垂直方向画素数 は，最小 $3 \times 3$ から最大 $33 \times 33$ まで 5 段階で設定できる。 このフィルタサイズのうち, 温度差の小さな領域での視認 性能を評価して, 本研究にふさわしいフィルタサイズを選 出した。そして局所フィルタ処理結果から, 通常行われて いる強調処理（本文では通常のエッジ強調処理と明記）と 新方式処理（本文では可変局所フィルタ処理と明記）との 比較を行って, 視認性改善効果を調べた。最後に HE 処理を 行って本システムで得られる最終処理画像を示した。

\section{〈3·1〉 赤外線画像における通常の視認性改善処理}

図 1(a)に YBCO ボロメータ検知方式の非冷却赤外線セン サ（画素数 $320 \times 240 ） に よ り$ 撮像した原画像を示す。比較的 高温度である人・車両・樹木等の存在は確認できるが，低 温度側の輝度差が小さいため，その詳細が判りづらい。図 1(b)は，HE 処理のみを行った画像である。原画像に比べ, ダイナミックレンジを有効利用したので, 画面全体のコン トラストは大きく見えるが，視認性に大きな変化はない。 視認性改善のためには，HE 処理を行う前に，目標物体の抽 出をする必要があり, その手段の一つとしてエッジ強調処

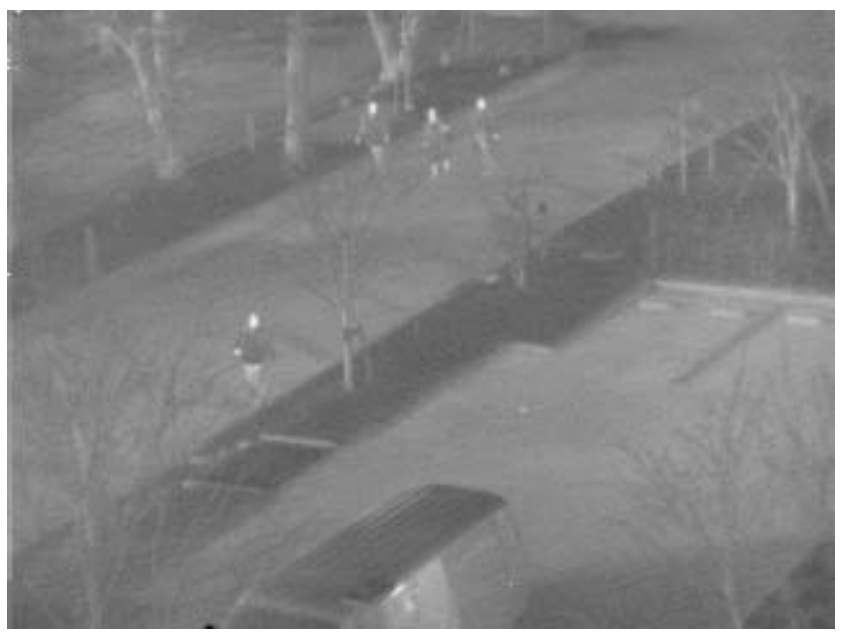

(a) 原画像

(a) The original image

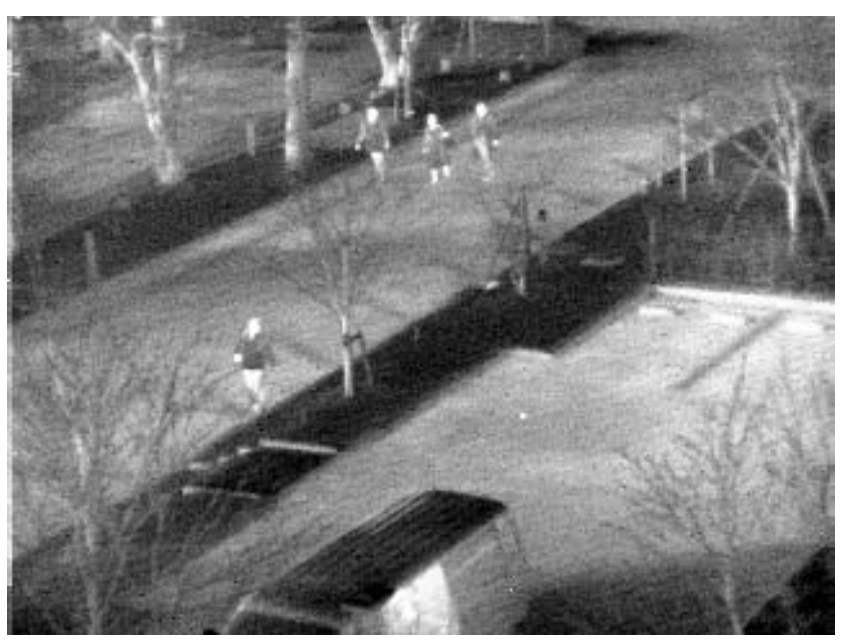

(b) ヒストグラム平坦化（HE）処理のみを実行した画像

(b) The histogram equalized processing image.

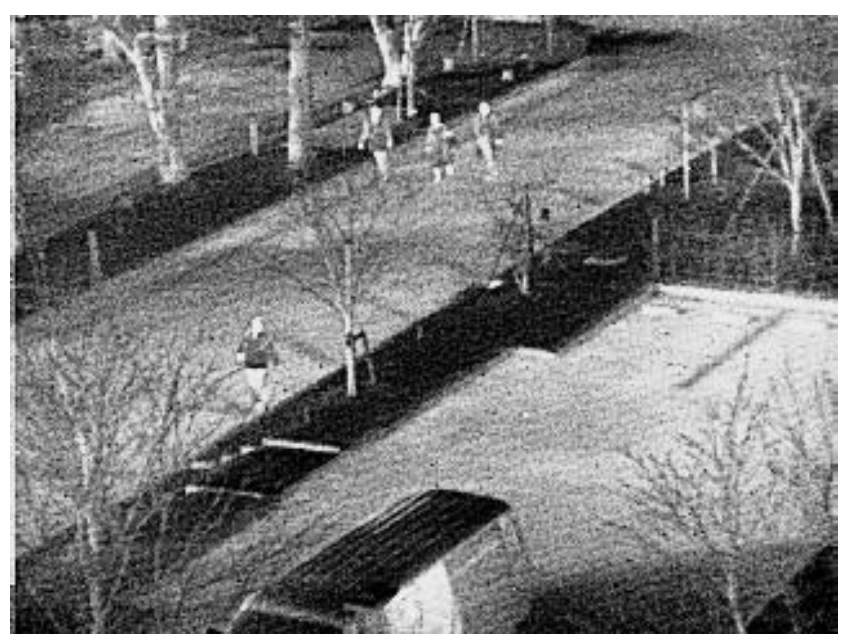

(c) 通常のエッジ強調後に $\mathrm{HE}$ 処理を実行した画像

(c) The edge enhanced and histogram equalized processing image.

図 1 非冷却赤外線センサによる赤外線画像

Fig. 1. Infrared images taken by the uncooled infrared sensor. 


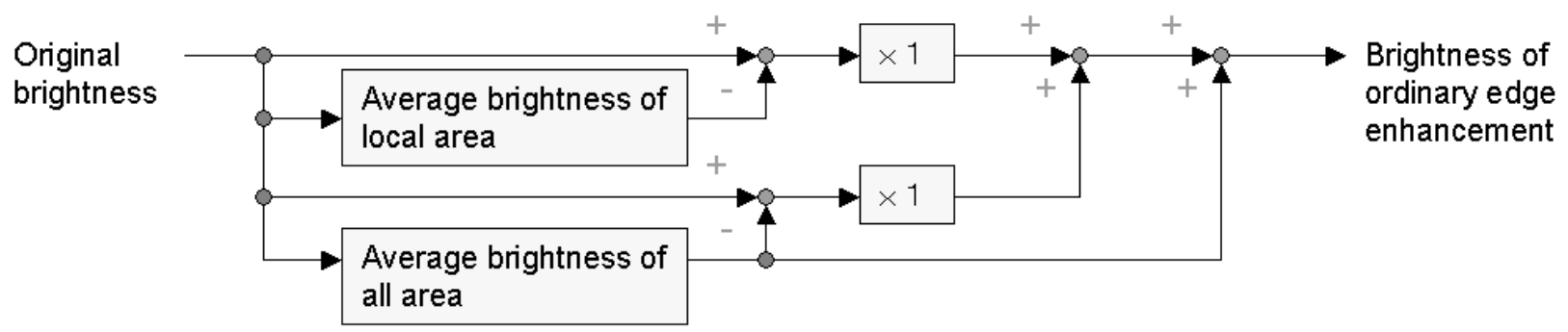

(a) 通常のエッジ強調処理

(a) The ordinary edge enhanced processing.

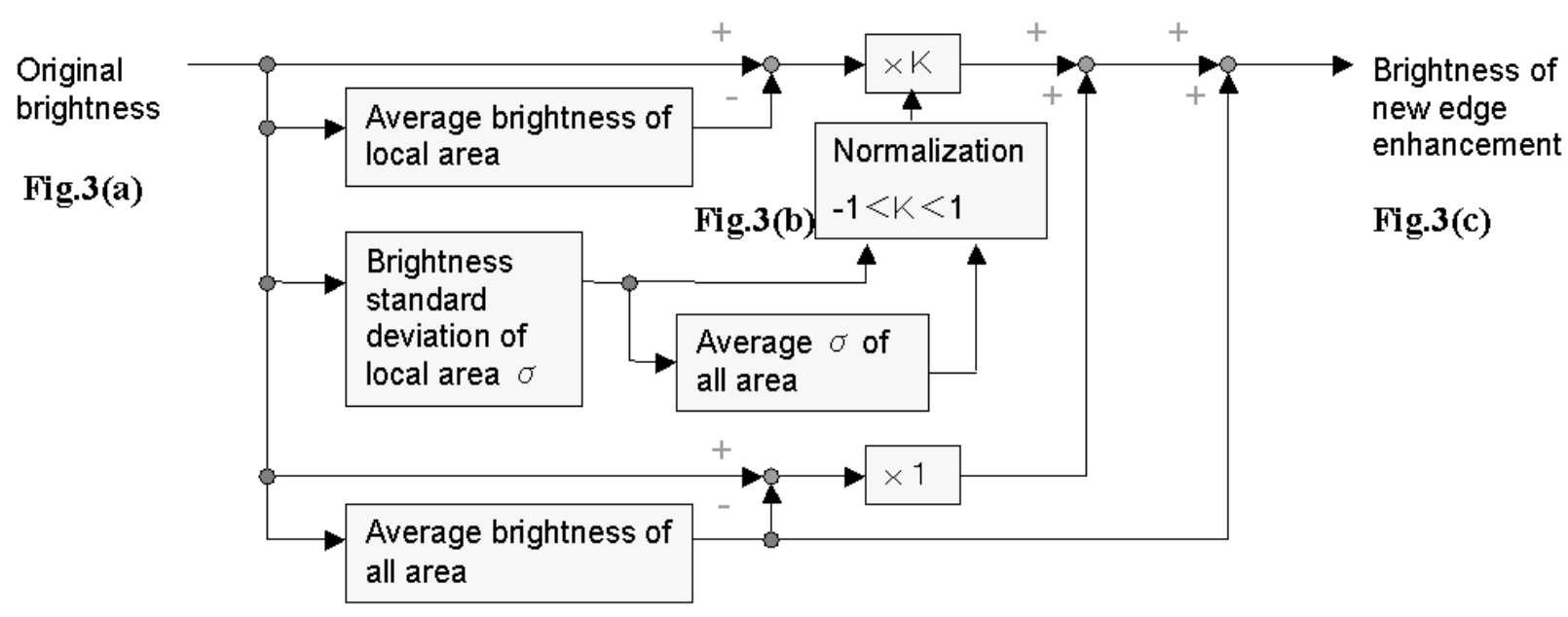

(b) 可変局所フィルタ処理

(b) The new enhanced processing.

図 2 各画像強調処理におけるブロック線図

Fig. 2. Block diagrams on each image enhance processing.

理が行われてきた。通常のエッジ強調処理を行った後に, $\mathrm{HE}$ 処理をした画像を図 1(c)に示す。人のように温度が高 く, コントラストが高い被写体では, 視認性が原画像 $\{$ 図 1(a)\}に比べて大きく向上する。しかし，路上のように温度 差の小さい所では，ノイズが強調されて逆に視認性が下が る。つまり, 従来型のフィルタ処理では，全画面を画一的 にエッジ強調するため, 目標抽出を改善する効果がある一 方，温度差の小さい領域においては，ランダムノイズが強 調されるため，視認性の低下が懸念される。

〈3・2〉新方式局所フィルタを用いた処理本研究で は, 通常のエッジ効果のみが働く局所フィルタを改良して, 新方式の局所フィルタを導入した。新方式の局所フィルタ を以下では可変局所フィルタと呼ぶ。この可変局所フィル タの特徵は, コントラストの低い領域では, エッジの強調 ではなくスムージングによりランダムノイズを抑制するこ とである。通常のエッジ強調処理とともにその概要を図 2(a),(b)に示す。通常のエッジ強調処理では，平均輝度より も高い輝度をもつ領域に対して, 平均輝度からの差を大き くするような輝度を加え, 画像を強調してきた。図 $2(\mathrm{a})$ も その一つで，全画面及び局所的な平均輝度に関して，それ ぞれの平均輝度よりも高い輝度をもつ領域では，平均輝度 から上まわった輝度差がそのまま加算される。

一方, 可変局所フィルタの概要を図 $2(\mathrm{~b})$ に示す。全画面
平均輝度以上をもつ領域の輝度が強調される点は, 通常の エッジ強調処理と同じであるが，局所領域における強調過 程が通常のエッジ強調処理と異なる。相違点は局所領域平 均輝度からの輝度差が $\mathrm{K}$ 倍されて加算されることである。 (1)式に K の表式を示す。

$$
\mathrm{K}=\frac{\sigma^{2}-(\bar{\sigma})^{2}}{\sigma^{2}+(\bar{\sigma})^{2}}
$$

ここで， $\sigma$ は局所的な輝度標準偏差， $\bar{\sigma}$ は全画面の輝度 標準偏差である。K は-1 から 1 までの值をとり， $\sigma \geqq \bar{\sigma}$ 即 ち局所領域の輝度分布が全面平均の輝度分布よりも大きい 場合は， $0 \leqq \mathrm{~K} \leqq 1$ であり局所輝度分布が大きい領域ほど $\mathrm{K}$ は大きくエッジが強調される。一方 $\sigma<\bar{\sigma}$ の領域では, -1 $\leqq \mathrm{K}<0$ であり局所輝度分布が小さい領域ほど輝度が大き く減算されて, 結果的にスムージングが働く。この処理過 程を図 2(b) 中で指示した図 3 (a)〜 (c) に示す。図 3 (a) は原画 像であり, 図 3 (b)は $\mathrm{K} に よ る$ 判別の基礎となる画像, そし て図 3(c) 変司所フィルタ処理の画像である。図 3 では, 各画素に $128(\mathrm{~K}+1)$ に相当する輝度をつけ，K>0 では輝度 が高く, $\mathrm{K}=0$ は中間色を示し, $\mathrm{K}<0$ では輝度が低く表され ている。ここで図 3(a) と図 3 (b) を比較すると, 図 3 (a)でコ ントラストが高い所は, 輝度標準偏差 0 が大きいため, 図 3 (b)ではエッジが強調されて白く表示されている。逆に Fig.3 (a)で温度差が小さい所は $\sigma$ が小さいため, 図 3 (b)ではスム 


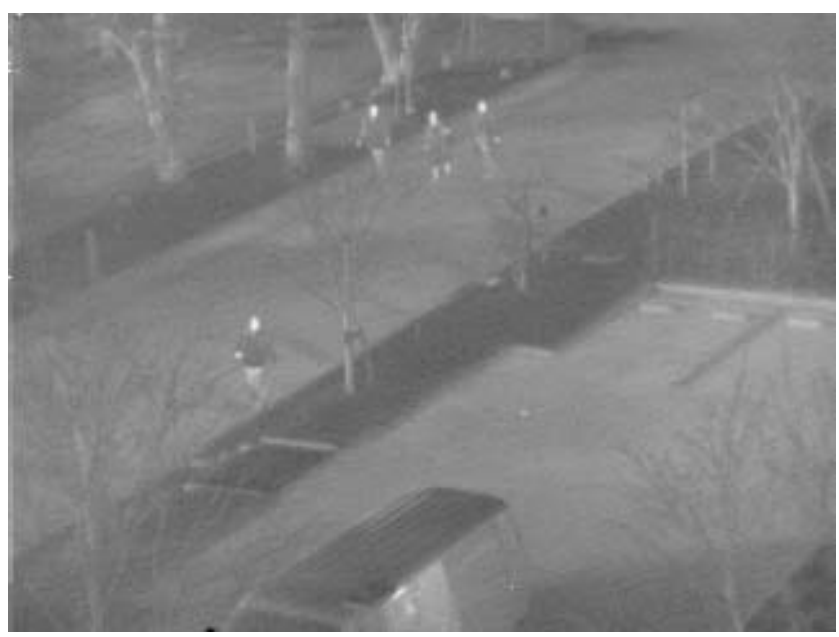

(a) 原画像

(a) The original image.

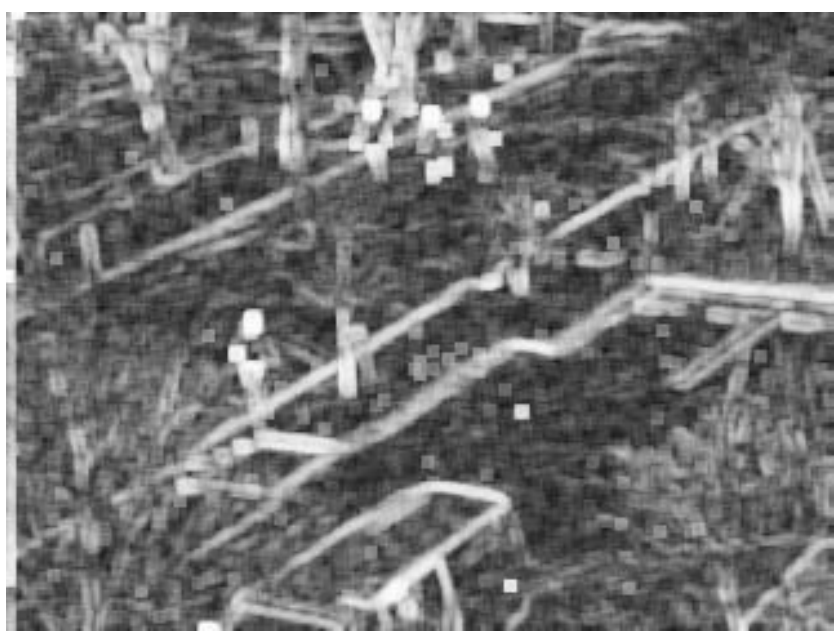

(b) K による判別の基礎となる画像

(b) The enhanced $\mathrm{K}$ \{defined in eq.(1)\} image

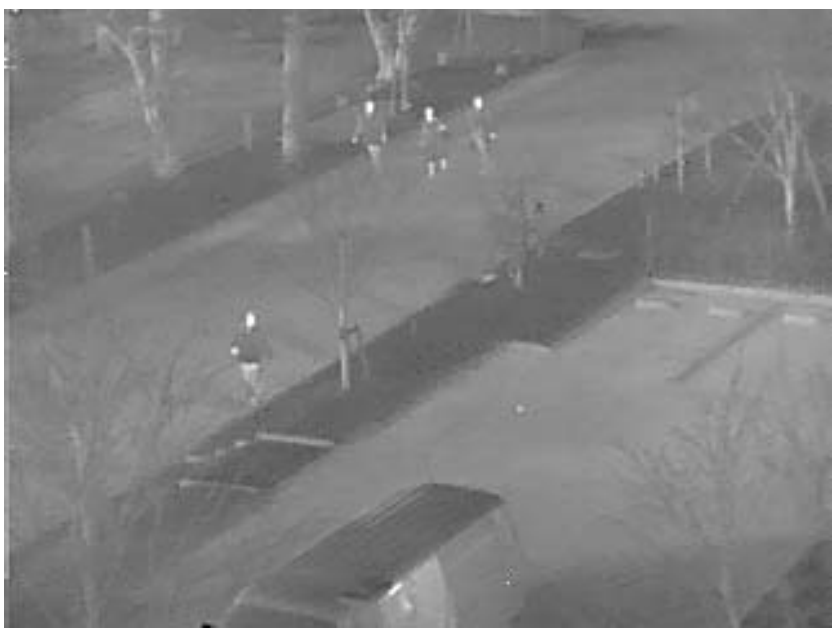

(c) 可変局所フィルタ処理後の画像

(c) The new processing image.

図 3 可変局所フィルタ処理過程における赤外線画像

Fig. 3. Infrared Images of the new processing.
ージングがなされて黒く表示されている。さらに, 図 3 (a) と図 3 (c)を比較寸ると, 原画像でコントラストが高い所は, エッジが強調されてシャープに見える一方, 温度差が小さ い所は，スムージングによりノイズが抑制されている。

次に $\mathrm{K}$ に関する画像と可変局所フィルタ処理画像におけ る局所フィルタサイズ依存性を調べた。各画像の画素数は $320 \times 240$ である。図 4 に示すように局所フィルタサイズが大 きくなるにつれて, エッジが強調される高輝度領域と, ス ムージングされる低輝度領域が拡大され，9×9 以上のフィ ルタサイズでは物体の識別が困難になる。図 5 で示す可変 局所フィルタ処理画像では, この K 画像が直接反映される。 フィルタサイズの増加に伴い高輝度領域（人や木等）と低 輝度領域（植え込み等）は明確になるが, 温度差の大きな 領域（人と路上の境界等）では，画像強調範囲が広すぎる ため, エッジにぼけが生ずる。

具体的に図 4,5 における輝度ヒストグラムを調心゙，それ を図 6(a),(b)に示す。図6(a)の K 画像においては, フィルタ サイズが増加寸るにつれて, 次第に輝度分布が狭くなり, $\mathrm{K}$ がとりうる範囲が狭くなる。つまり，フィルタサイズが大 きくなることで画像強調効果に偏りが発生すると考えられ る。図 6(b)では, 可変局所フィル夕処理後の全領域画素にお ける輝度分布を示す。原画像では多くの特徵的なピークを もつ輝度分布であるが, フィルタサイズの増加と共に, こ れらのピークが消失してなだらかな輝度分布になる。この 原因としては, フィルタサイズが増加すると画像強調効果 が偏り，微細な輝度差が失われるためと考えられる。

以上の結果をふまえると, フィルタサイズが大きくなる と, 特定の画像強調効果が強くなり目標抽出効果が期待で きるが，その一方で原画像がもっていた微細輝度差が失わ れや寸くなる。つまり, 視認性を改善しようとする対象物 の大きさに対して最適なフィルタサイズが存在すると考え られる。本研究のように $20 \times 20$ 画素程度の人等に関する視 認性を向上させる場合には, 数画素程度の微細構造情報も 重要なのでフィルタサイズは人等より十分小さい必要があ り, フィルタサイズとしては $9 \times 9$ より小さい方が適当であ る。ただし, フィルタサイズ $3 \times 3$ における人等の画像強調 効果は小さい $\{$ 図 5(b) $\}$ ことを考慮して, 以後の画像処理は フィルタサイズ $5 \times 5$ で行うこととした。

〈3·3〉新方式局所フィルタにおけるスムージング効果 ここでは，可変局所フィルタによってもたらされるエッ ジ強調とスムージング効果について評価した。評価の対象 にした画像領域は, 図 7 で示寸温度差が小さい路上である。 評価手順としては, まず, 図 7 の拡大図で示す中央 4 画素 分の高輝度領域を目標領域として設定し, 通常のエッジ強 調処理と可変局所フィルタ処理を行った。次に, 高輝度の 目標領域とその周辺部で, 温度差の小さい背景領域 (160 画 素分）が処理方式によりどのように変化するのか確かめた。 各処理ごとの輝度分布を図 8 に示し, さらに算出した各領 域における平均輝度等を表 2 に示す。はじめに目標領域平 均輝度に注目すると, 通常のエッジ強調処理では原画像に 


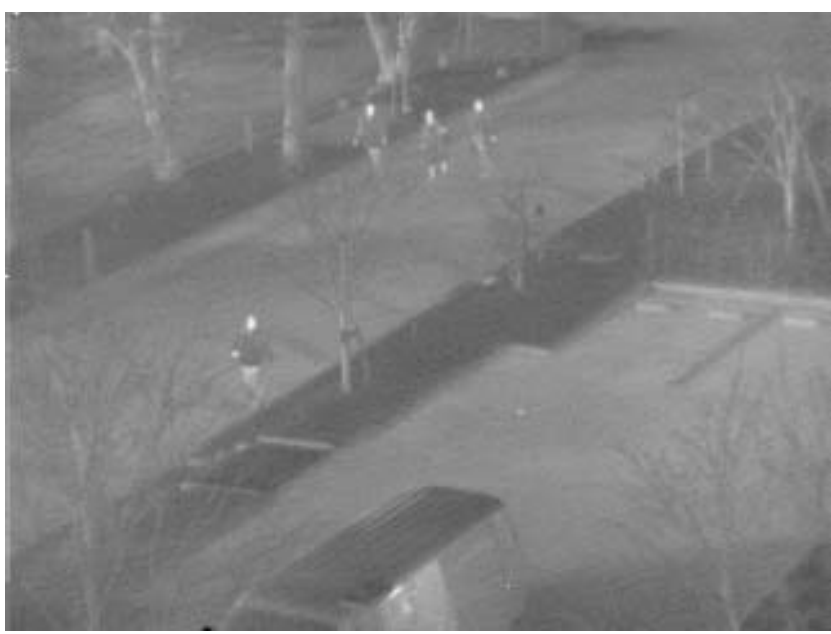

(a) 原画像

(a) The original image.

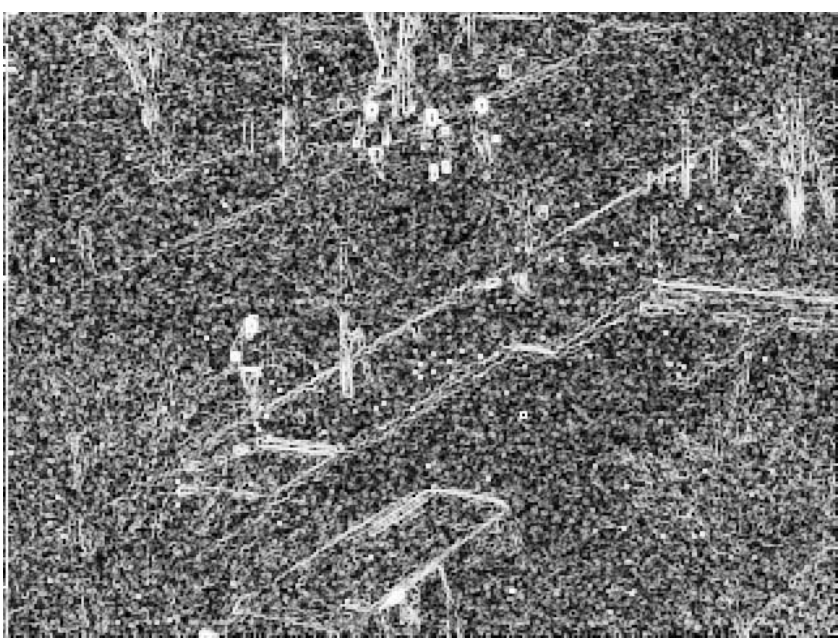

(b) フィルタサイズ $3 \times 3$ における $\mathrm{K}$ の分布画像

(b) The enhanced $\mathrm{K}$ image of $3 \times 3$ filter size.

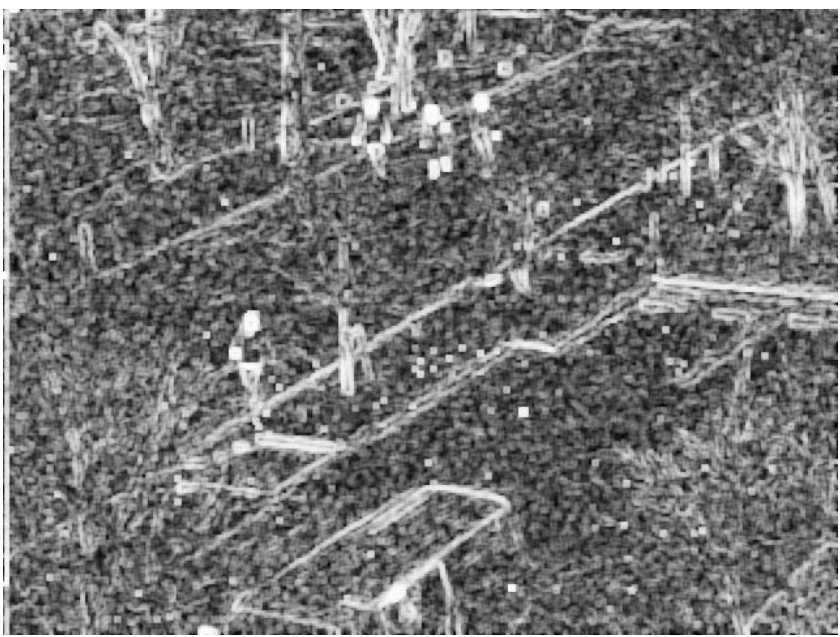

(c) フィルタサイズ $5 \times 5$ に打ける $\mathrm{K}$ の分布画像

(c) The enhanced $\mathrm{K}$ image of $5 \times 5$ filter size.

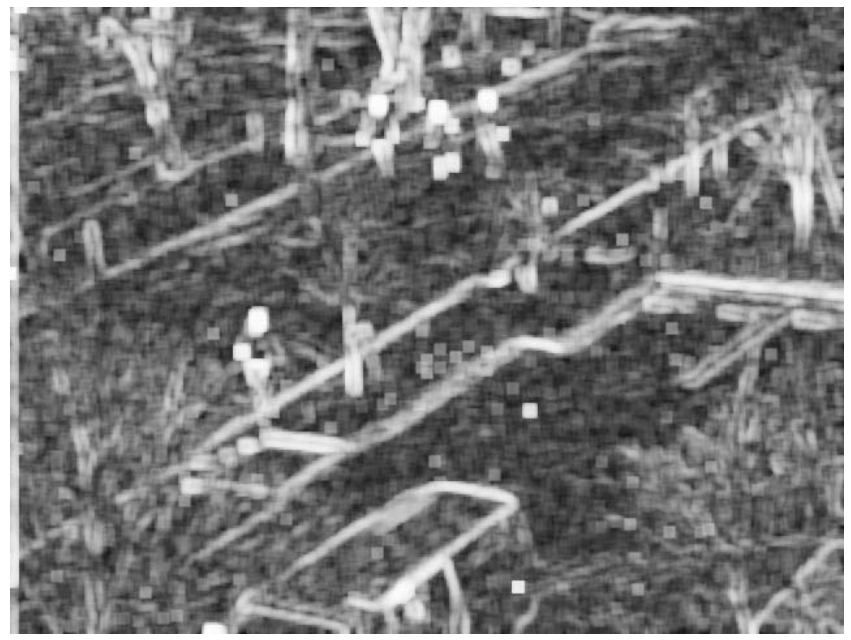

(d) フィルタサイズ $9 \times 9$ における K の分布画像

(d) The enhanced $\mathrm{K}$ image of $9 \times 9$ filter size

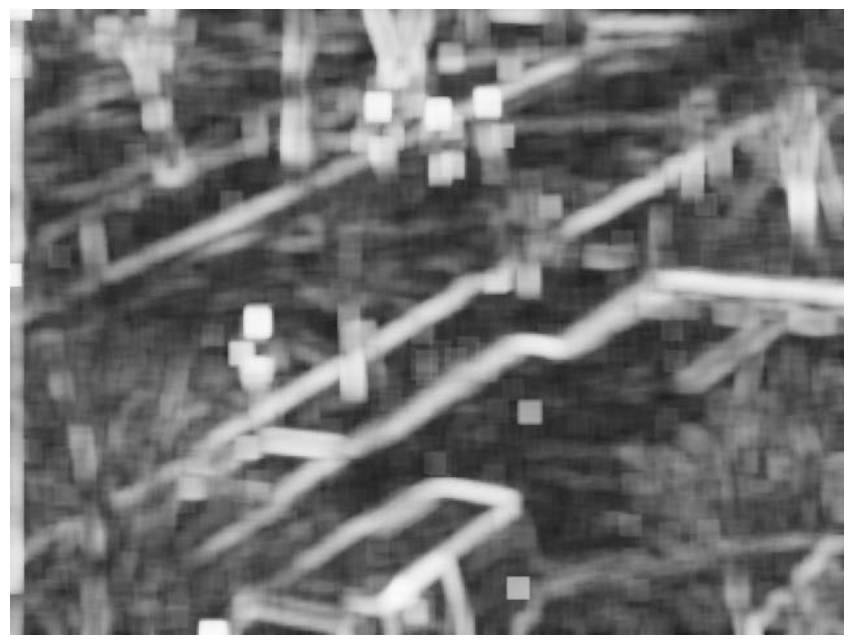

(e) フィルタサイズ $17 \times 17$ における K の分布画像

(e) The enhanced $\mathrm{K}$ image of $17 \times 17$ filter size.

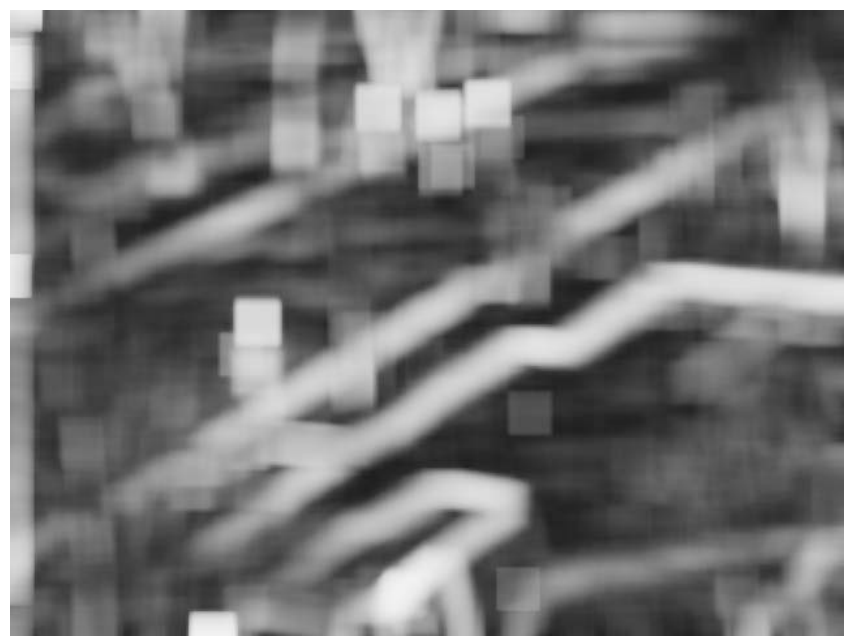

(f) フィルタサイズ $33 \times 33$ における K の分布画像

(f) The enhanced $\mathrm{K}$ image of $33 \times 33$ filter size.

図4 K の分布画像における局所フィルタサイズ依存性

Fig. 4. Filter size dependence of enhanced $\mathrm{K}$ images. 


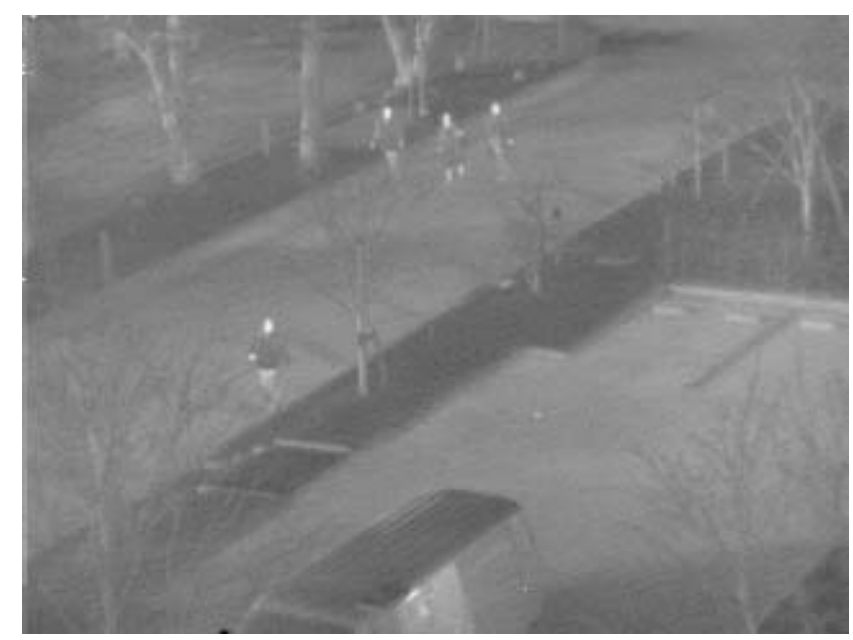

(a) 原画像

(a) The original image.

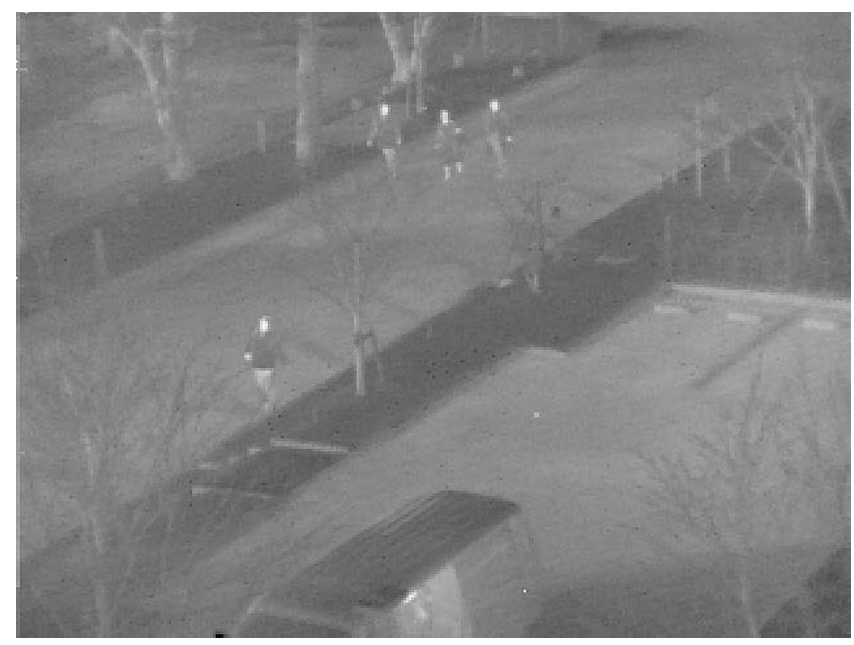

(b) フィルタサイズ $3 \times 3$

(b) The enhanced image of $3 \times 3$ filter size

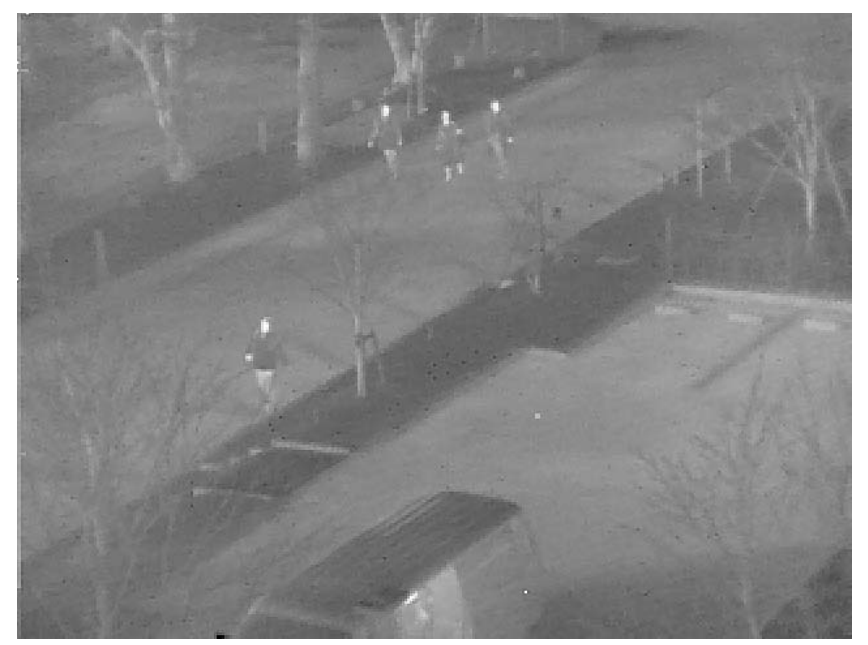

(c) フィルタサイズ $5 \times 5$

(c) The enhanced image of $5 \times 5$ filter size

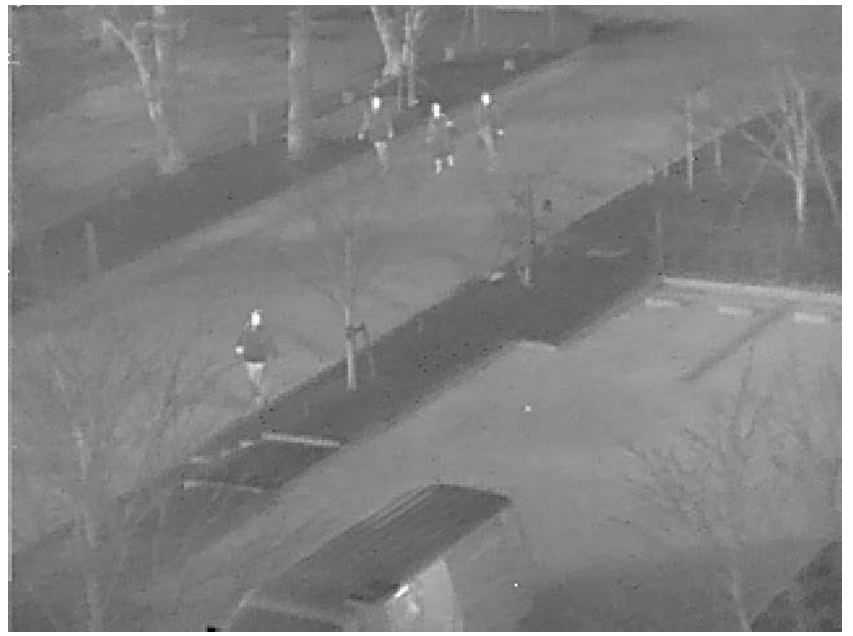

(d) フィルタサイズ $9 \times 9$

(d) The enhanced image of $9 \times 9$ filter size.

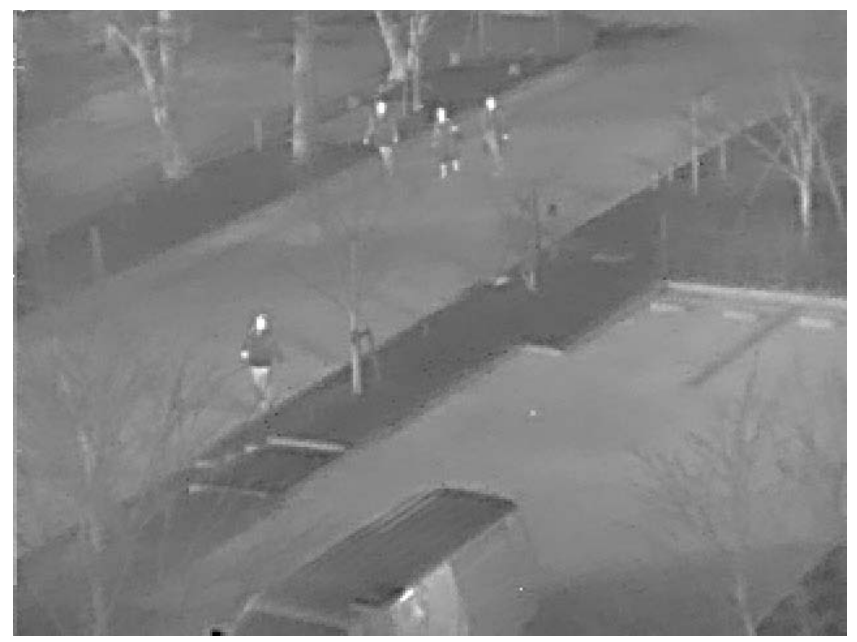

(e) フィルタサイズ $17 \times 17$

(e) The enhanced image of $17 \times 17$ filter size

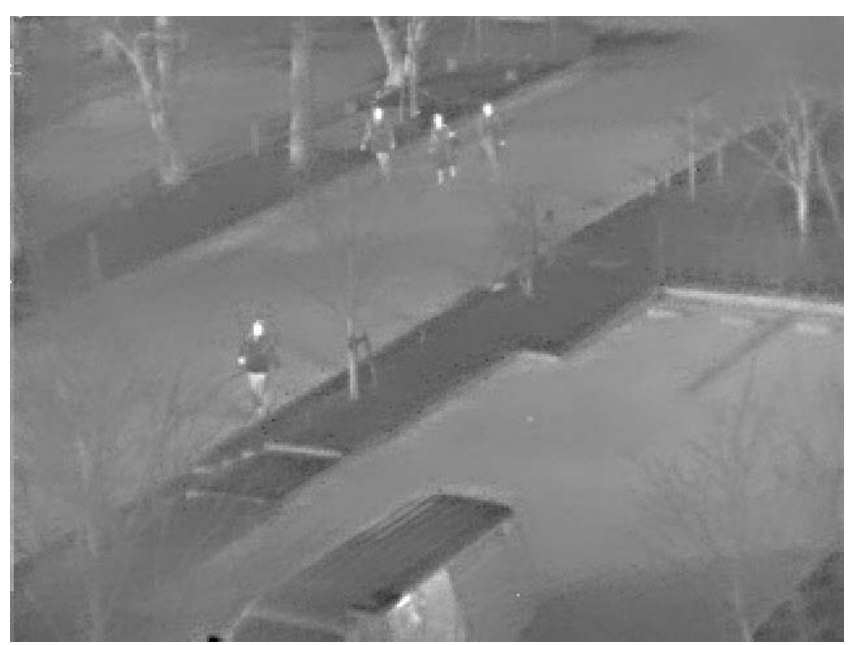

(f) フィルタサイズ $33 \times 33$

(f) The enhanced image of $33 \times 33$ filter size.

図 5 可変局所フィルタ画像におけるフィルタサイズ依存性

Fig. 5. Filter size dependence of enhanced images by the new processing. 


\section{K value}

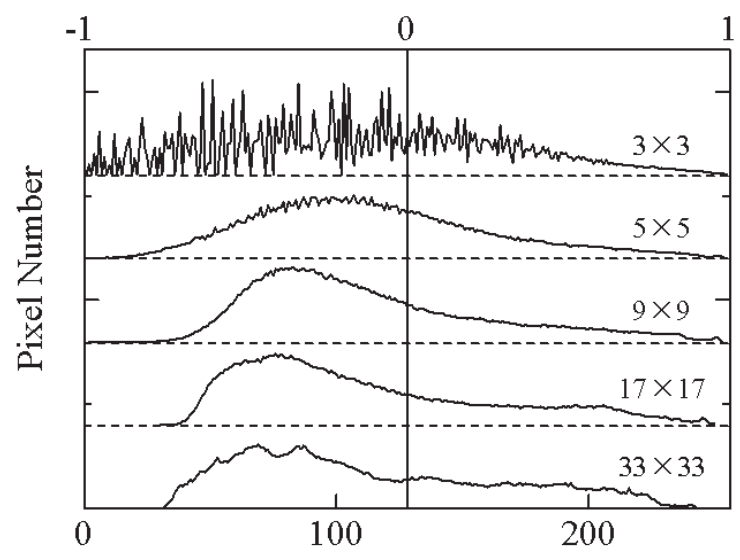

Brightness of all area

(a) Kによる画像（図 4) の全領域輝度分布

(a) Brightness distribution in all areas of $\mathrm{K}$ image (shown in Fig.4).

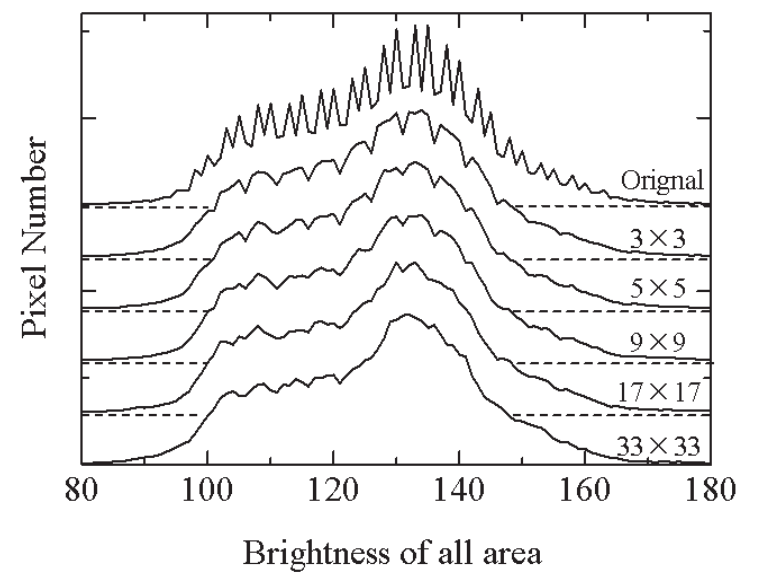

(b) 局所フィルタ処理画像（図 5) の全領域輝度分布

(b) Brightness distribution in all areas of enhanced image by the new processing (shown in Fig.5).

図 6 輝度分布におけるフィルタサイズ依存性

Fig. 6. Filter size dependence of Brightness distribution by the new processing.
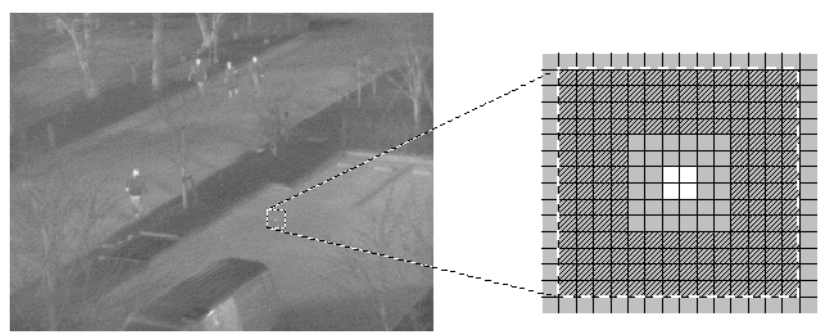

$\boxplus$ Target area Background area

図 7 目標領域及び背景領域の明示図

Fig. 7. Target area and background area.

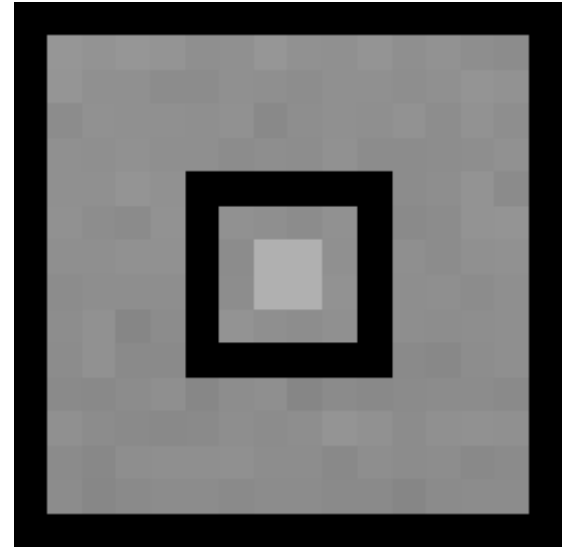

(a) 原画像における目標及び背景領域図

(a) Target area and background area in original image.

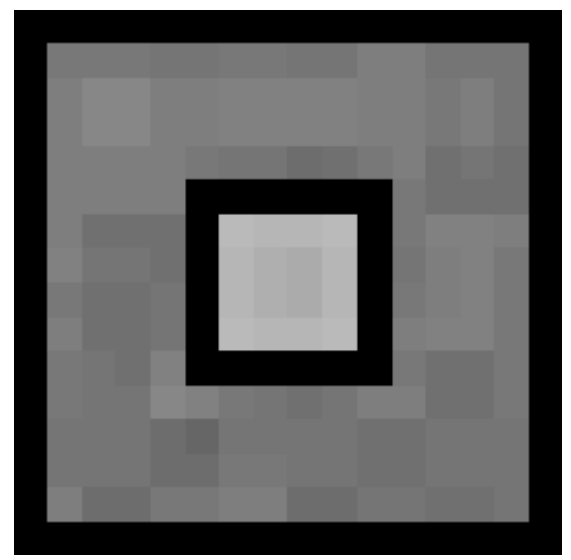

(b) 通常のエッジ強調を行った画像における目標及び背景領域図 (b) Target area and background area in ordinary edge enhanced image.

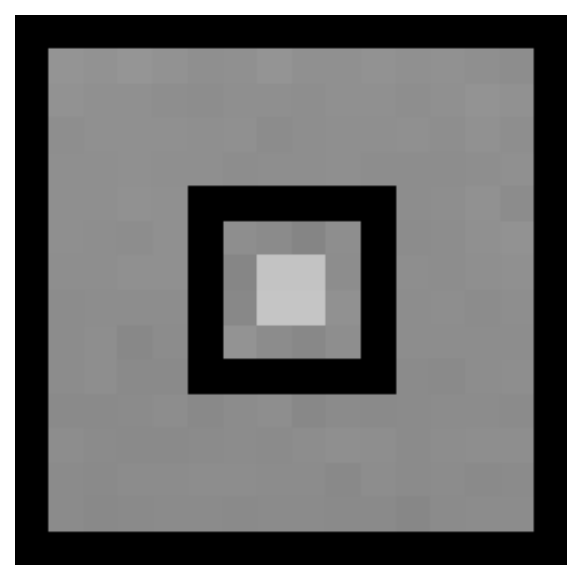

(c) 新方式局所フィルタ処理における目標及び背景領域図

(c) Target area and background area in the new enhanced image.

図8 画像強調処理における輝度分布（目標及び 背景領域図のうち, 内黑枠内が目標領域輝度分布, 外黒枠内が背景領域輝度分布を表す)。

Fig. 8. Brightness distribution of each enhanced image. (Inner bright pixels (4 pixels) are target area. Outer bright pixels (160 pixels) are background area). 


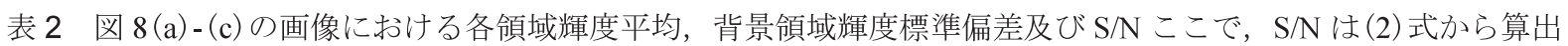

Table 2. Average brightness of each area and brightness standard deviation of the background area, and S/N calculated by eq.(2).

\section{Average brightness of target area $\langle\mathrm{T}\rangle$ \\ Average brightness of background area $\langle\mathrm{B}\rangle$}

Brightness standard deviation of $S / N$ background area $\sigma_{\mathrm{B}}$

\begin{tabular}{|c|c|c|c|c|}
\hline The original image & 22600.0 & 18228.4 & 422.9 & 10.34 \\
\hline $\begin{array}{l}\text { The ordinary edge } \\
\text { enhanced image }\end{array}$ & 26217.5 & 18216.1 & 736.0 & 10.87 \\
\hline $\begin{array}{l}\text { The new enhanced } \\
\text { image }\end{array}$ & 25228.8 & 18235.1 & 317.2 & 22.05 \\
\hline
\end{tabular}

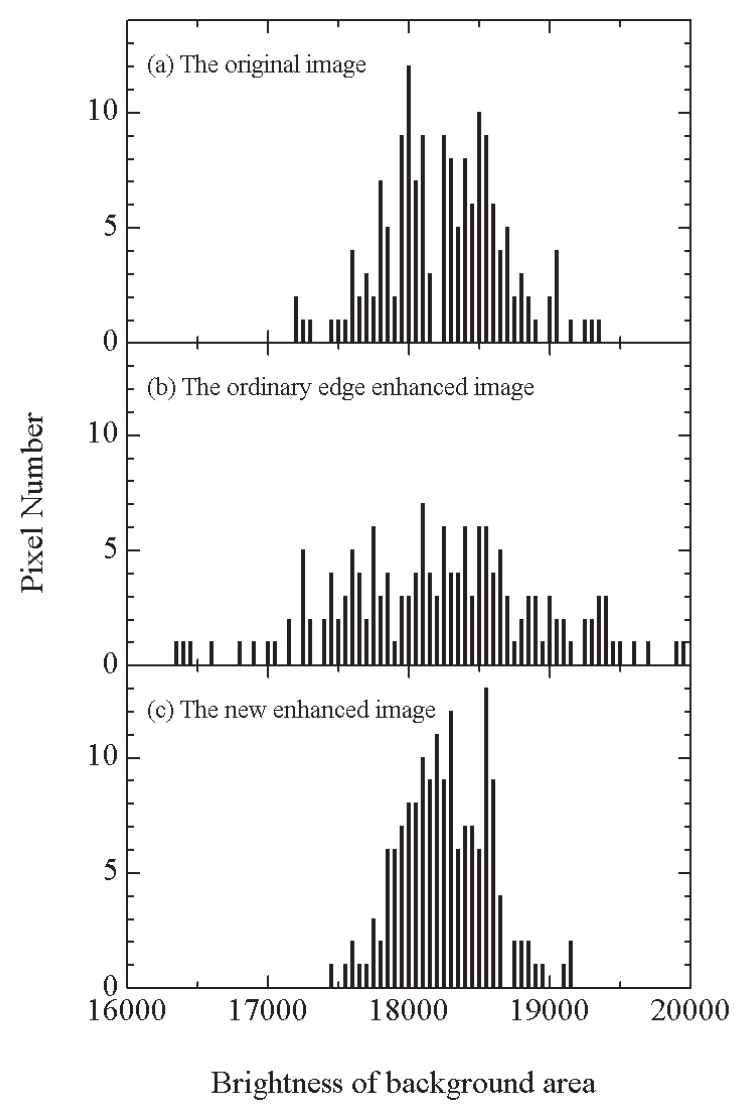

図 9 強調処理画像における背景領域輝度の 画素数ヒストグラム

Fig. 9. Brightness histogram in background area of enhanced images.

比べて輝度が $16 \%$ 増加している。同様に可変局所フィルタ 処理でも輝度が $12 \%$ 増加し, 可変局所フィルタでもエッジ 強調効果が維持されていることがわかる。次に背景領域の 平均輝度は, 各処理とも大きな差はないが, 図 8 に示した 背景領域を見ると, 通常のエッジ強調処理では原画像より 輝度分布が大きくなる一方 $\{$ 図 8(b) $\}$, 可変局所フィルタで はスムージング効果により背景領域輝度が，原画像に比べ て一定になる $\{$ 図 8(c) $\}$ 。背景領域の輝度分布については, 図 9 に表すような輝度ヒストグラムを用いてさらに分析を

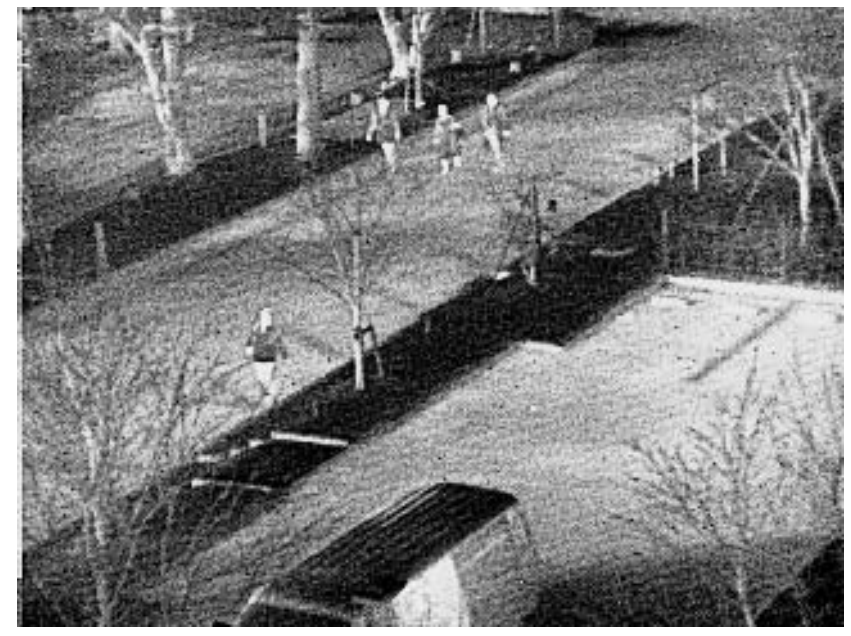

(a) 通常のエッジ強調処理画像

(a) The ordinary edge enhanced image.

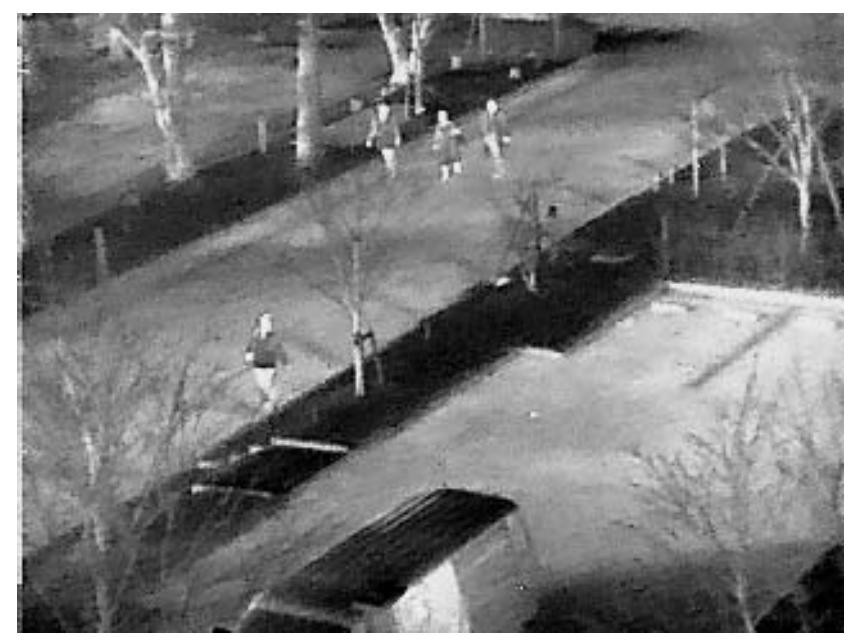

(b) 可変局所フィルタ処理画像

(b) The new enhanced image.

図 10 強調処理後に HE 処理を実行した画像

Fig. 10. Enhanced and histogram equalized processing images.

行った。原画像のヒストグラムでは $17200 １ 9400$ までの背 景領域輝度分布であったが $\{$ 図 9(a) \}, 通常のエッジ強調処 理ではそれが 16300〜20000まで広がり, 分布中心も不明確 
である $\{$ 図 9(b) \}。一方, 可変局所フィルタ処理を用いた場 合のヒストグラムでは, 背景領域輝度平均を中心に 17400 〜 19200 までの狭い分布を示している $\{$ 図 9(c)\}。これはス ムージングが有効に機能し, 背景領域輝度が平滑化された ことを表している。

また, 表 2 における背景領域輝度標準偏差は, 背景領域 輝度分布が処理方式に大きく依存していることを示してい る。目標領域と背景領域の輝度差と, 背景領域輝度標準偏 差との関係が, その画像が視認性能に優れた良質画像かど うかを判断する基準になると考えられる。ここで, エッジ 強調とスムージングの効果により, 背景領域の視認性能が どれくらい改善されているかを評価するため, 表 2 の值を 用いて式(2)のように定義した $\mathrm{S} / \mathrm{N}$ による比較を試みた。

$$
\mathrm{S} / \mathrm{N}=\frac{<\mathrm{T}>-<\mathrm{B}>}{\sigma_{\mathrm{B}}}
$$

この(2)式を用いて算出した原画像及び各処理画像の $\mathrm{S} / \mathrm{N}$ は表 2 の右端に示してある。可変局所フィルタ処理を行っ た画像では，上記したように，エッジ強調効果を保ちつつ， スムージング効果でノイズによる輝度分布を抑えるため, 他の画像と比較して $\mathrm{S} / \mathrm{N}$ が 2 倍程度向上している。

〈3.4〉最終処理画像図 10(a)に通常のエッジ強調処 理後に HE 処理を行った画像, 図 10(b)に可変局所フィルタ 処理後に HE 処理を行った画像を示す。可変局所フィルタ処 理を経た画像では，人の歩く姿勢や木の植生等の詳細まで 判別でき, 通常のエッジ強調処理に比べて視認性が大幅に 向上している。

\section{4. 結 論}

今回, 非冷却赤外線センサシステムの視認性向上のため, 通常のエッジ強調に改良を加えた可変局所フィルタを導入 した。その結果, 熱源のエッジ強調効果を保ったまま, 背 景領域のノイズを抑制することにより，視認性に優れた鮮 明画像を得ることができた。このような簡易なシステムで 視認性向上が可能であったことから, 今後非冷却赤外線セ ンサシステムの汎用化が進むにつれて，このような画像処 理システムに対する需要は，ますます高くなるであろうと 考えられる。

(平成 15 年 3 月 25 日受付, 平成 15 年 8 月 25 日再受付)

\section{文献}

(1) P. W. Kruse and D. D. Skatrud : "Uncooled Infrared Imaging Arrays and Systems", (Academic Press, San Diego, 1997) Semiconductors and Semimetals, Vol.47

(2) P. W. Kruse : "Uncooled Thermal Imaging Arrays, Systems and applications", (SPIE Press, Washington, 2001) Tutorial Texts in Optical Engineering, Vol. TT51

(3) H. Wada, T. Sone, H. Hata, Y. Nakaki, O. Kaneda, Y. Ohta, M. Ueno, and M. Kimata : "YBaCuO Uncooled Microbolometer IRFPA", Sens. \& Mater. 12 , p.315 (2000)

(4) K. Takahashi : "Adaptive Dynamic Range Improvement Method for Recognition of Detailed Information", M. S. Thesis, Graduate School of Science and Technology, Keio University (1999) (in Japanese)
高橋耕生 : 「視認性向上のためのダイナミックレンジ改善法」, 平 11 慶應義塾大学理工学部修士論文

(5) A. Rosenfeld and A. C. Kak : "Digital Picture Processing", Academic Press (1976) (in Japanese)

A. Rosenfeld, A. C. Kak :「デジタル画像処理」，(監訳) 長尾 真，株 近代科学社, p.177 (1978)

(6) M. Nagao : "Pattern Information Processing", Inst. Electron. Commun. Eng. Jpn., Vol.1-4, p.57 (1983) (in Japanese)

長尾 真: パターン情報処理, 㑣コロナ社, 電子通信学会編, 電子 通信学会大学シリーズ, Vol.1-4, p.57 (1983)

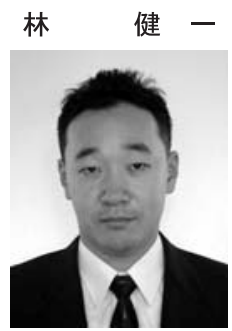

（非会員）1993 年名古屋大学理学部物理学科卒 業。95 年名古屋大学大学院理学研究科物理学専 攻博士前期課程修了。96 年名古屋大学大学院理 学研究科物質理学専攻博士後期課程中退。同年 防衛庁技術研究本部入庁。2002 年慶應義塾大学 大学院理工学研究科物質科学専攻後期博士課 程修了。赤外線検知素子材料および赤外線セン サシステムの研究に従事。現在, 防衛庁技術研 究本部第 2 研究所第 3 部光波電子戦研究室員。博士 (工学)。日本 物理学会会員。

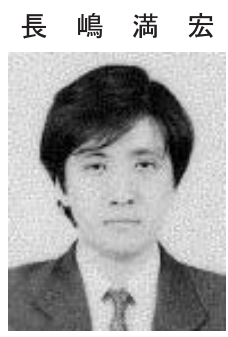

（非会員） 1990 年東京大学理学部物理学科卒 業。92 年防衛庁技術研究本部入庁。赤外線受光 素子の材料・デバイスの研究開発に従事。現在, 防衛庁長官官房情報通信課部員。博士（工学）。 応用物理学会会員。

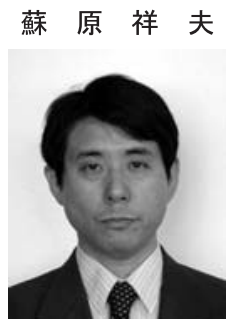

（非会員）1982 年東京理科大学工学部電気学科 卒業。同年防衛庁技術研究本部入庁。赤外線セ ンサシステムの研究開発に従事。現在, 第 2 研 究所第 3 部光波電子戦研究室長。日本光学会, 計測自動制御学会会員。

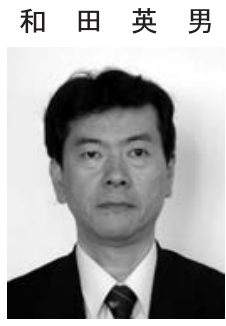

(正員) 1980 年防衛大学校理工学部電気工学科 卒業。85 年防衛大学校理工学研究科物理工学専 攻修士課程修了。 88 年三井金属鉱業(1侏総合研究 所研究員。93 年防衛庁技術研究本部第 2 研究所 第 3 部光波第 4 研究室主任研究官。赤外線検知 素子および材料の研究に従事。現在, 第 2 研究 所研究調整官。工学博士。日本赤外線学会, 応 用物理学会, 電子情報通信学会, SPIE 会員。

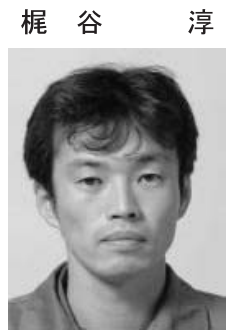

(非会員) 1994 年早稲田大学理工学部電気工学 科卒業。同年三菱電機㑣入社。主として赤外線 撮像装置に関わる制御装置及び画像処理装置 の開発に従事。 